\title{
The Integrative Transition in the Islamic Style between The Mamelukes' and Ottoman Eras (Analytical Study of Interior Design of Sunqur Al Saadi School and the Dervish Theater "Sama Khanna" - Cairo, Egypt)
}

\author{
Nada Ahmed Arisha \\ AssistantProfessor Interior Design Department,Faculty of Arts and Design, \\ October University for ModernSciences and Arts (MSA)
}

\begin{tabular}{l|l|l} 
Submit Date: $2021-03-25$ 13:29:02 & Revise Date:2021-08-17 17:30:28 & Accept Date: 2021-09-15 05:42:14
\end{tabular}

DOI: 10.21608/jdsaa.2021.69467.1102

\section{KEYWORDS:}

The Islamic (architecture, Interior design) style - Mamelukes complex building - Integrative Transition - The mamelukes' style - Ottoman buildings style - Sunqr Al-Saadi Madarasa (School) in Cairo - The Samaa khanna - ,The Dervish (Sufism) Theatre.

\begin{abstract}
:
Islamic Egypt (Cairo) is rich in many heritage buildings that expressed the Integrative transition in the Islamic style between different eras through Place and Time, and also through the effect of Restoration in the conservation of heritage buildings. The Integrative Transition is embodied in both Historical and Symbolic values that constitute the architectural and Interior design features, as well as the various determinants of Islamic-styles. The research includes studying aspects of the transition in the Islamic style between the Mameluks and Ottoman eras and how they were integrated into the architectural and interior design of Sunqur Al Saadi Madarasa (School) "Mameluks era" and the Dervish Theater "The Ottoman-style". The Complex Building of Sunqur Al Saadi Madarasa (School) and the Dervish Theatre was restored and renamed as The Mevlevi "Mawlaweyya" Museum (The Italian Institute of Culture and the Egyptian Antiquities Organization-Cairo, Egypt); as a place integrated through two different eras in Islamic Architecture and Interior design.
\end{abstract}

\section{Introduction:}

Sunqur Al Saadi Madarasa (School) and the Dervish theatre reveal The Integrative Transition through History on the same building. The Complex signifies the unity of Islamic Styles such as the Mameluks and the Ottoman eras on which the building was built. Egypt Restored the Complex with the cooperation of the Italian Institutes for preservation and restoration of the Heritage building and it was renamed as "Mawlayeyya/Mevlevi Museum" which referred to the Mawalayeya as a religious determinant related to "Jalal add Din Al Rumi" 1207-1237 (The Islamic Poet, The Scholar and The Founder of Mawlaweyya in Sufism*(Al Tassawof). The Research studies the aspects of transition through the two different Islamic Styles and how it was applied on Sunqur Al Saadi Complex on which the Dervish Theatre was built.

Research problem:
-Neglecting the study of the integrative transition in the Islamic style in the same building in Egypt.

\section{Research aims:}

The research aims to:

1. Documenting the architectural value of Sunqur Al Saadi (Hasan Sadaka School - Al Tekkia Al Mawlawia-Dervish Theater).

2. Studying the Integrative Transition in Sunqur Al Saadi School and the Dervish Theatre between the different Islamic Eras (The Mameluks and The Ottomans).

Research Methodology:

1. Historical Methodology: A study of the Mameluk and the Ottoman eras.

2. Descriptive and Analytical Approach: An analytical study of Sunqur Al Saadi School and the Dervish Theater. 
-Tools of Research: Interviews through the site visit of Sunqur Al Saadi School and The Dervish Theatre Camera for Taking photos.

\section{Research hypotheses:}

-Reaching the Integrative Transition in the Islamic style between the Mameluks and Ottoman eras in the Building of Sunqur Al Saadi School and the Dervish Theater (Al Mawlaweya Museum).

\section{The Philosophy of Integrative Transition in Is- lamic Buildings:}

Integrative Transition is a philosophy referred by the researcher to define the state of the same building after passing by different eras. This transition process occurs as a result of both Place and Time throughout history. In Egypt many Islamic Buildings expresses this Transition which appeared Integrated as a result of the effect of Historical, Religious, Cultural and Climatic determinants.

\section{Tha Mameluk Era-Historical Background:}

The Mameluk reigned the Arab World Era (from 1517:1250 A.D to 648:922 A.H( after the Ayyubid, and within the time the Mameluk started to rule Egypt and Egypt became the centre of Islamic Califat. The Mameluks belonged to different European and Asian Nationalities such as Turkish, Tattar, Chinese, Roman, Greek and Spanish.

The Mamelukes were divided to:

\section{-Maritime Mamelukes:}

Attributed to the Mameluks of the Ayyubid Sultan Najm al-Din Ayyub. Their surname because they were camping with him in his castle on the island of Manial al-Rawda in Egypt during his reign.

\section{-Tower Mamelukes:}

Attributed to the Mameluks who camp and guard the castle towers.

3. The Ottoman Era:

Ottoman Turks a tribe of Turks settled in Minor Asia, Osman and his successors were able to expand their kingdom in $1362 \mathrm{AD}$. After about a century the Turkish Ottomans conquered Constantinople in 1453 $\mathrm{AD}$ and made it the capital of their new kingdom.

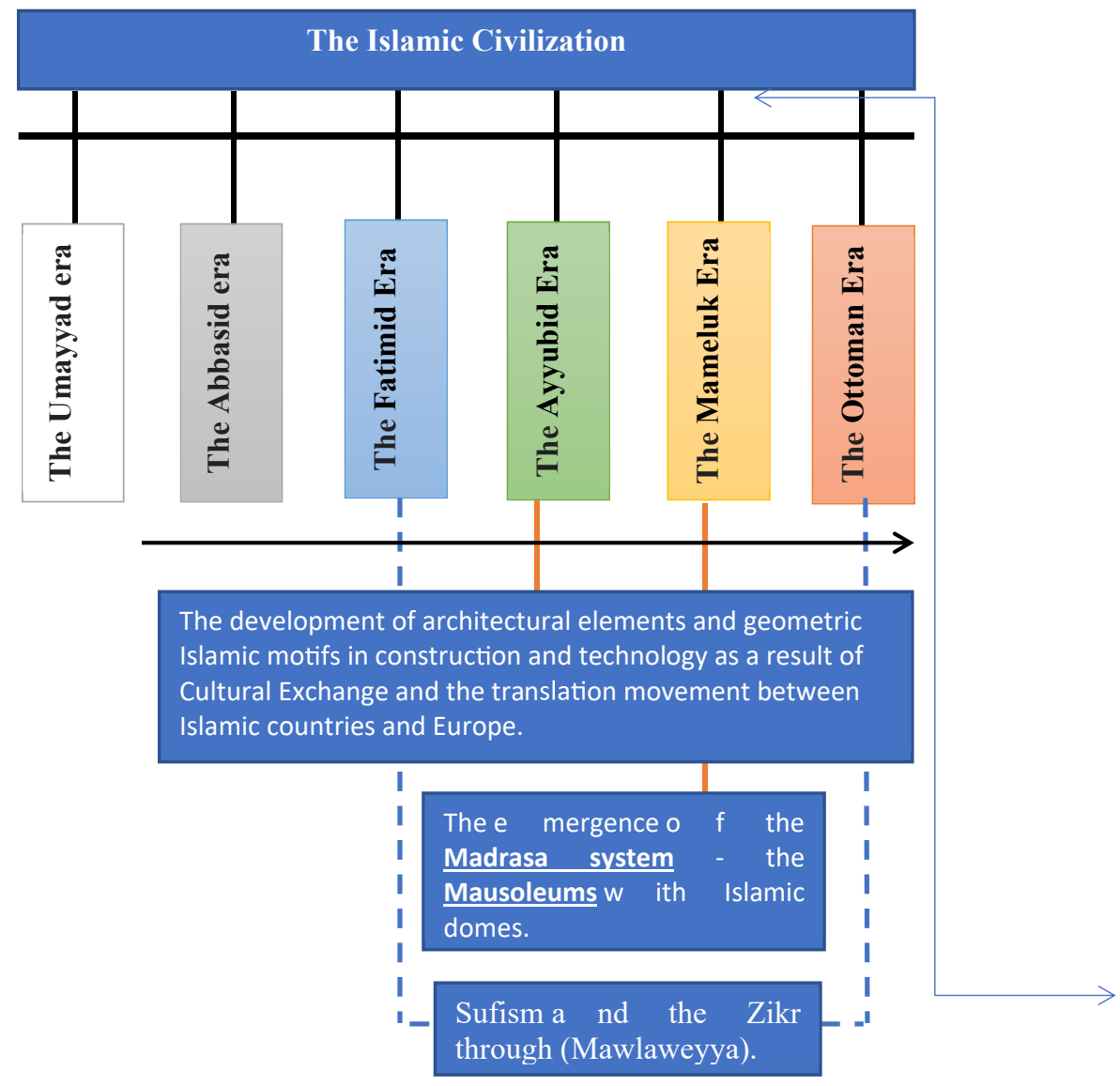


Figure 1 illustrates the Islamic Civillzation throughout the Islamic Eras. The Integrative Transition achieved through the eras by the development of the architectural and Interior design elements, also the Religious determinants through Islamic eras. (By Researcher)

The Research highlights the unity of the Integrative transition between the Mameluks and Ottoman era on the Building of Sunqur Al Saadi School (Madrasa) and the Dervish Theater "Sama Khanna" in Cairo, Egypt.

The Restoration of the building was launched in 1979, after an agreement between the Italian Institute of Culture and the Egyptian Antiquities Organization.

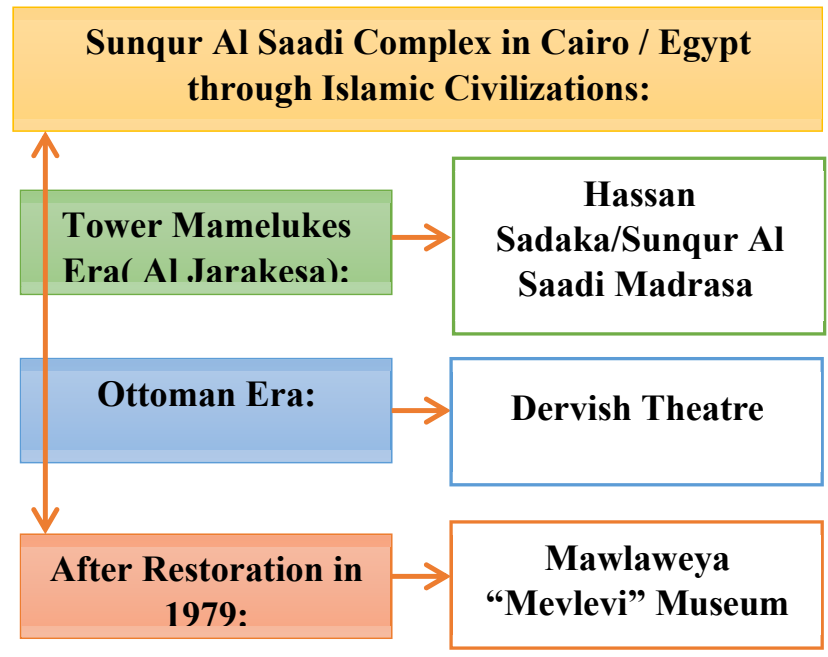

4. Sunqur Al Saadi School (Madrasa) and the Dervish Theater "Sama Khanna" - Cairo, Egypt):

4.1 Sunqur Al Saadi School (Madrasa) - The Mameluks Era:

The school was established by Prince "Sanqur Al-Saadi", captain of the Sultanate Mamluks in the year 715 Hijry -1315 AD, near Hadrat alBaqar on al-Suyufiyah Street-Egypt and that was during the reign of Sultan "Al-Nasir Muhammad Bin Qaloon" in the Mameluk era, which was characterized by luxury and wealth.

It is worth noting that Sanqur al-Saadi built a dome for himself attached to the school with a tomb to be buried in after his death. And he was buried there, so the shadow of his tomb and his wooden coffin engraved on it his name and titles were empty until Sheikh Nasir al-Din Sadaka was buried in it, one of the Sufi sheikhs.

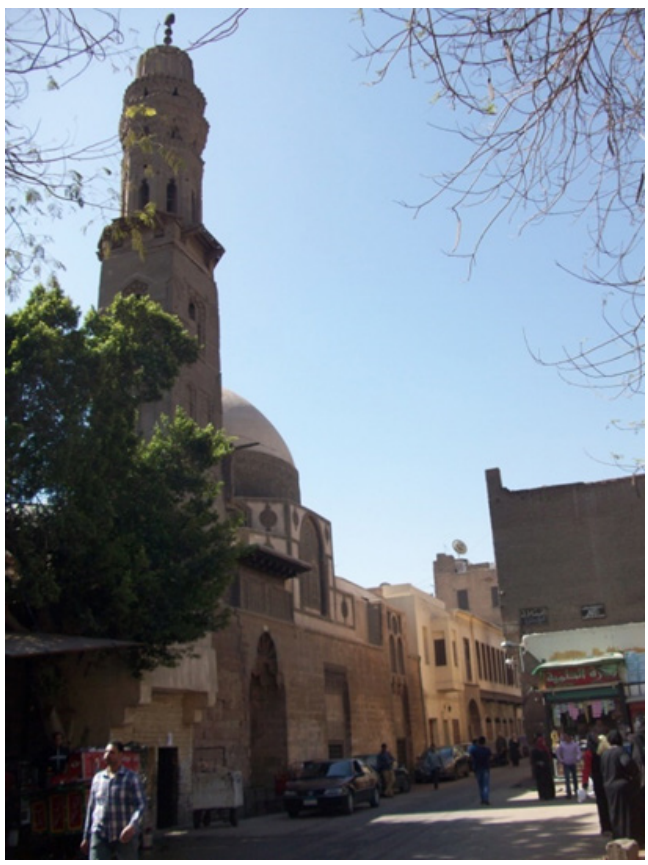

Figure 2 Illustrates the Entrance, The Dome and Minaret of Sunqur Al Saadi School at al-Suyufiyah Street-Egypt. (Photographed by Researcher)

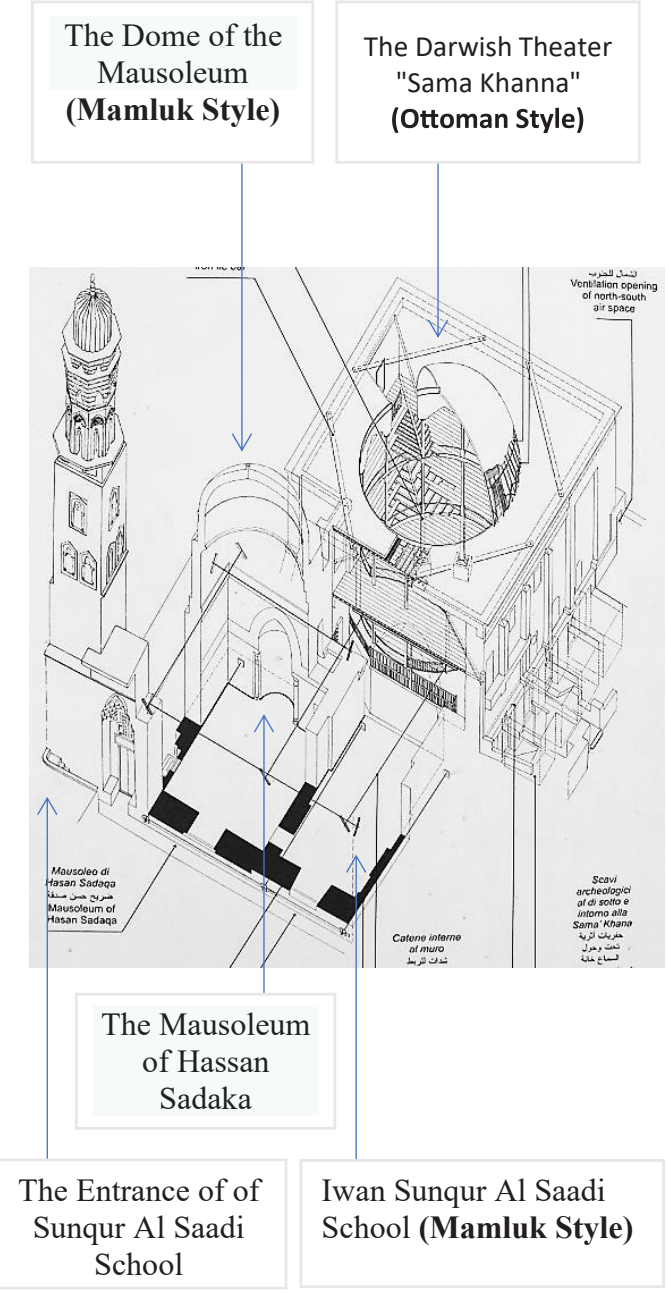




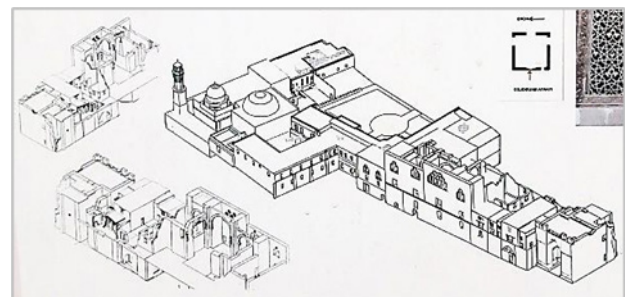

Figure 3 illustrates perspectives of the Comnplex of Sunqur Al Saadi school - The Darwish Theatre and the Mevlevi Tekeyya (All Photos and Diagrams photographed by Researcher in the Mawlaweya Museum-Egypt)

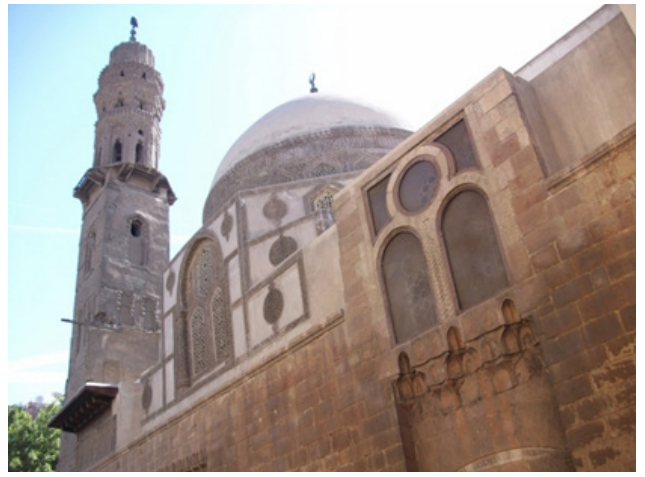

Figure 4 The Dome and the Minaret of Sunqur Al Saadi School (Photographed by Researcher)
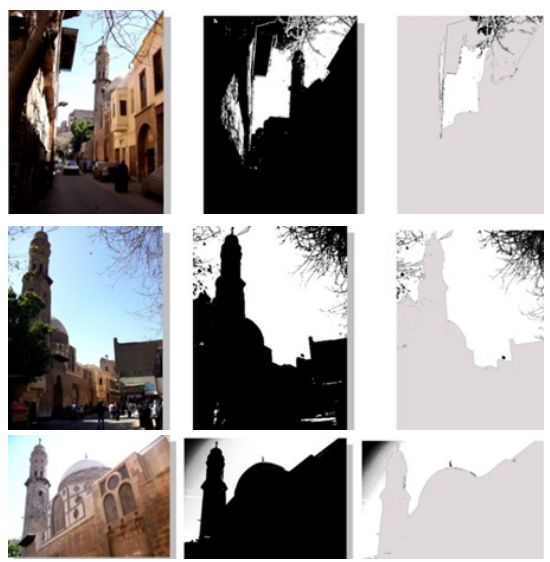

Figure 5 indicates the Sky Lines with the Entrance of Sunqur Al Saadi School. (Photographed by researcher)

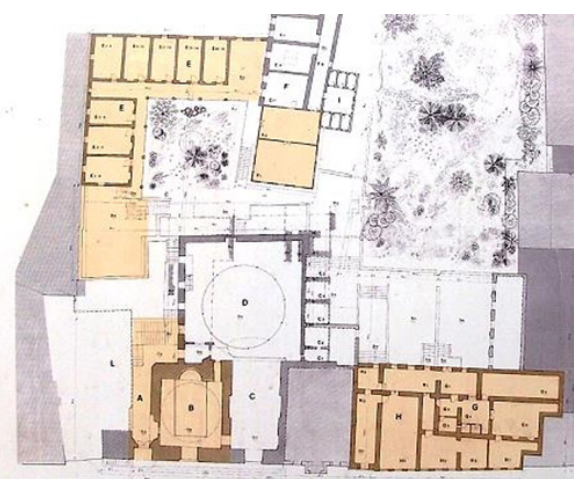

Figure 6 Indicates the Plan of the Complex (Photographed by researcher in the Mawlawya Museum-Egypt)

\subsection{The Dervish Theater "Sama Khanna"- The Ottoman Era:}

The Whirling Dervishes "Darwish" settled in the area that Prince Youssef Sinan gave them represented by the Complex of Sunqur Al-Saadi and the Yashbak Palace, and they lived there for a period of time and practiced their religious rituals inside it in places suitable for use at that time.

They remained this way for a long period of time, until the year 1005 Hijri-1095 AD, when they completed the extension of the Mevlevi Buildings which were built at a height of three meters from the school of Sunqur Al Saadi.

The Dervish Theatre "Zikr Mawlawi” hall, adjacent to it is a building for al-Khalawi for the establishment of the Sufi (Tekkeyat al-Mawlawi), while using as much as possible the antiquities that existed before, after it was prepared for the new function.

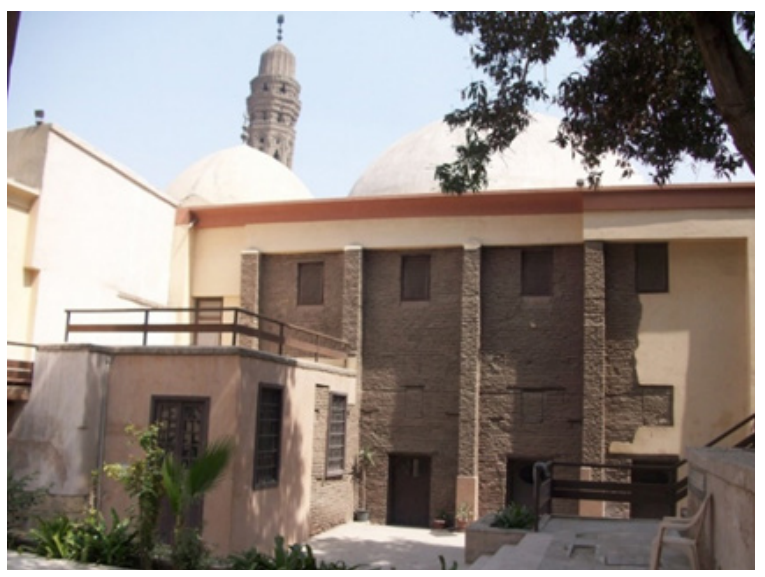

Figure 7 indicates the Entrance of The Dervish Theatre "Sama Khana-Ottoman Era" which was built on Sunqur Al Saadi school -Mameluks Era. (Photographed by researcher)
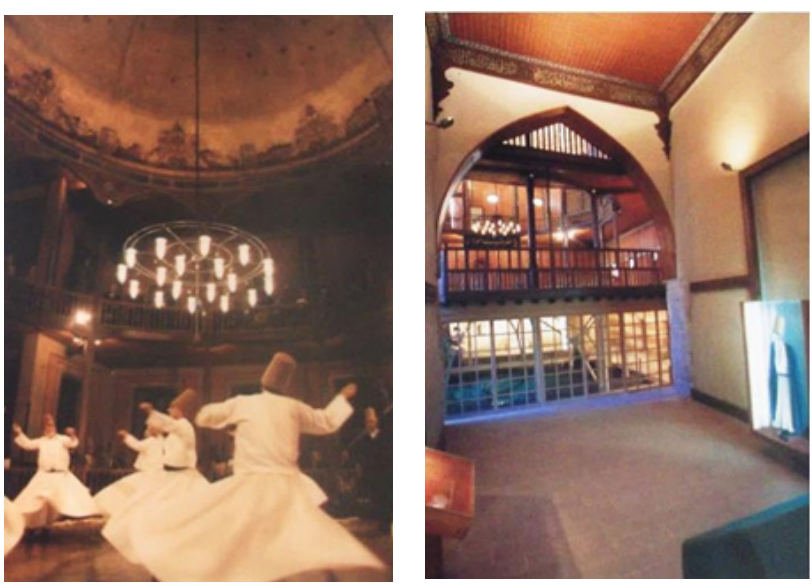

Figure 8 illustrates the Interior Design of Dervish Theatre with Mawlaweya (The Whirling Dervishes). Photographed by researcher 
5-The Integrative Transition through Architecture and Interior Design Analysis of Sunqur Al Saadi School and the Dervish Theater "Sama Khanna":

The Integrative Transition in this Building expressed through the different Islamic styles passes by the building in Time. Sunqur Al Saadi School and the Dervish Theater "Sama Khanna" represent the transition of Mameluks style to Ottoman style in the same building and express the unity of Islamic Architectural and Interior design elements and Motives.

\subsection{Entrance:}

\subsubsection{The Mameluk Entrance:}

-The entrance is located in the northeastern side, and it has a regular door opening that leads to the school (Madrasa) and to the shrine dome.

-This entrance was closed after the construction of the Dervish Theater (Ottoman Era), and it became the main entrance from the Ottoman era.

\subsubsection{The Ottoman Entrance:}

- The entrance is located in the northwestern region, overlooking Al-Sioufia Street - Egypt.

-It is considered the main entrance to the Mameluk School (Madrasa) and the Ottoman Dervish Theater.

-Written on its façade (the Mevlevi Museum) after the restoration affiliated to the Italian-Egyptian Center for Restoration and Antiquities

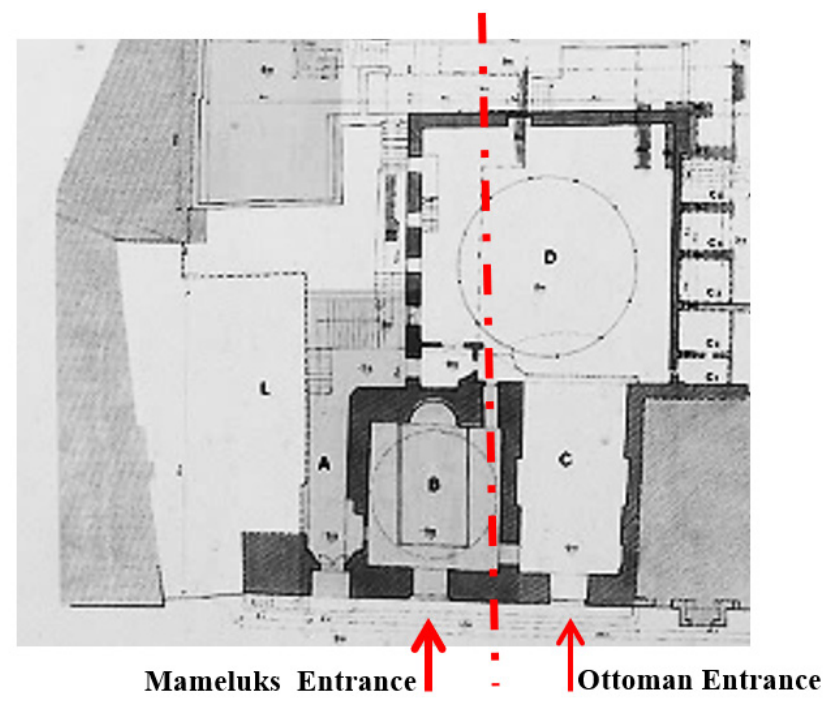

Figure 9 indicates the Mameluks and Ottoman Entrance in the building.
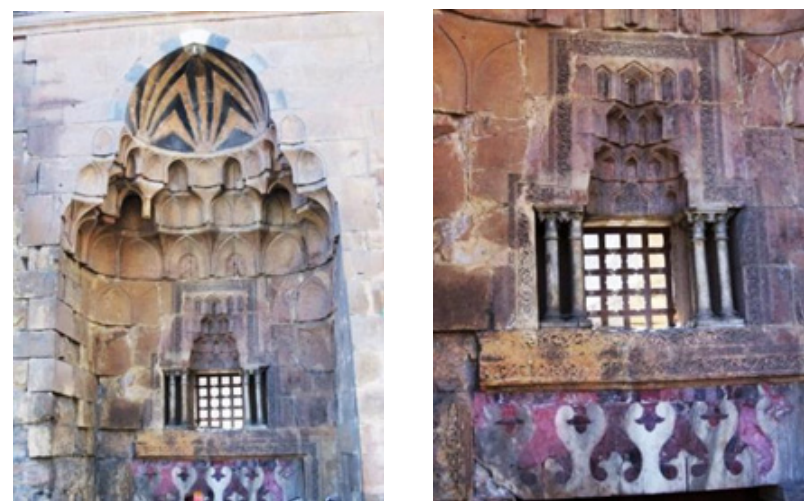

Figure 10 and Figure 11 illustrates a part of the Mameluks gate of Sunqur Al Saadi School. The architectural elements used was "Al Muqarnas" as a Transitional element on the Gate. The Natural Materials used was "Al Ablaq" which is Black and Light Brown Rocks forming the Arch. (By Researcher)
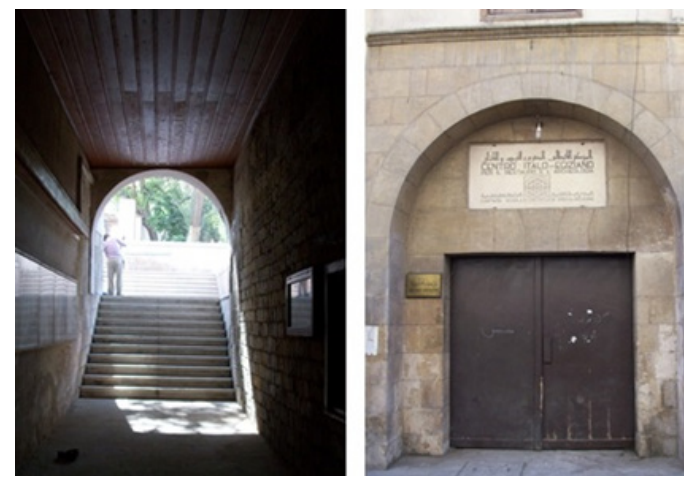

Figure 12 illustrates the Ottoman Entrance from outside and inside of the Dervish Theatre. The Gate written on it The Mawlaweyya Museum "The Italian-Egyptian Center for Restoration and Antiquities

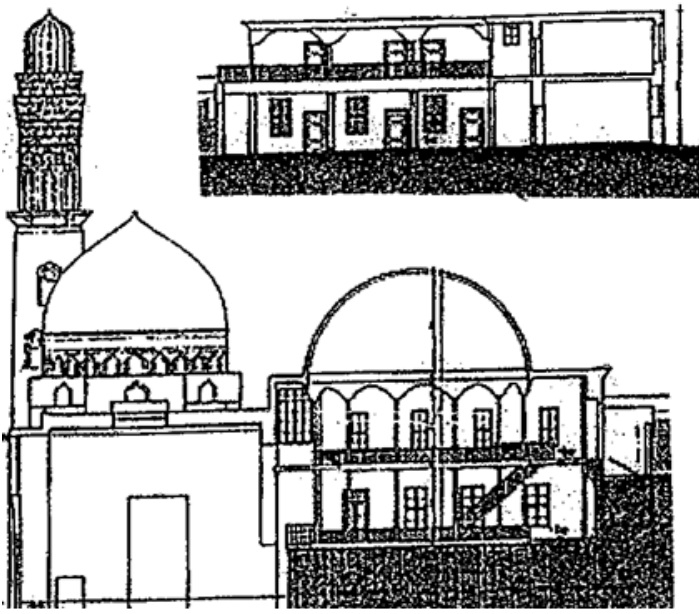

Figure 13 Section illustrats the Mausoleum dome of sunqur Al Saadi (Mameluks Part) and the Dervish Theatre (Ottoman Part) -All photos and Diagrams photographed by Researcher in the Mawlaweya Museum-Egypt.

-All photos and Diagrams photographed by Researcher in the Mawlaweya Museum-Egypt. 


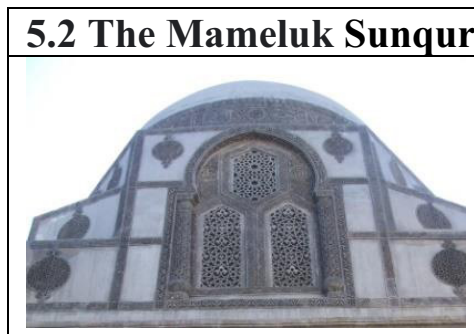

Figure 14 illustrates the Sunqur Al Saadi Mausoleum Dome

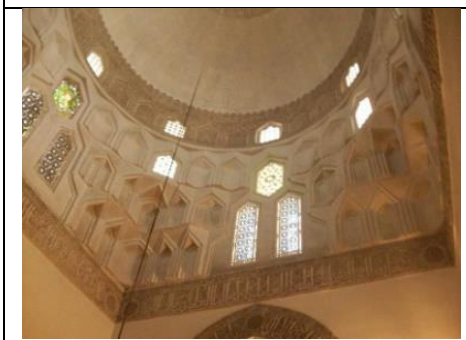

Figure 15 illustrates the dome from inside. Islamic Muqarnas and stained glass were used in the interior design of the Mausoleum dome.
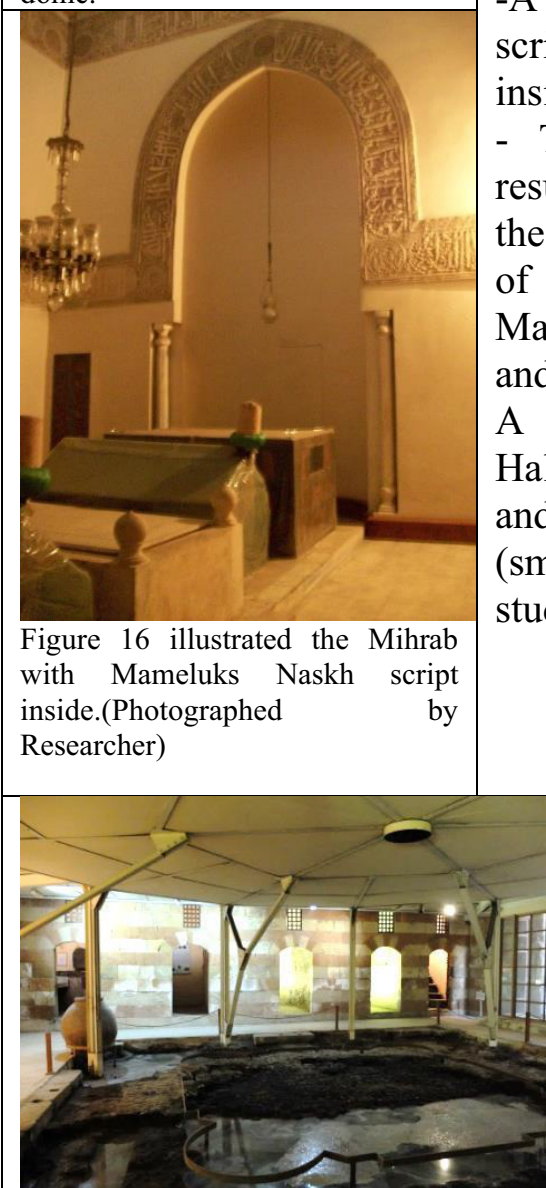

Figure 17 illustrates the restoration inside the Mameluks Madrasa of sunqur Al Saadi on which the Ottoman Dervish theatre was built on it. The picture illustrates the presence of Central open Hall AND Khalawat (small rooms) for students to study Islamic Religion

\subsection{The Ottoman Dervish Theater "Sama Khanna":}

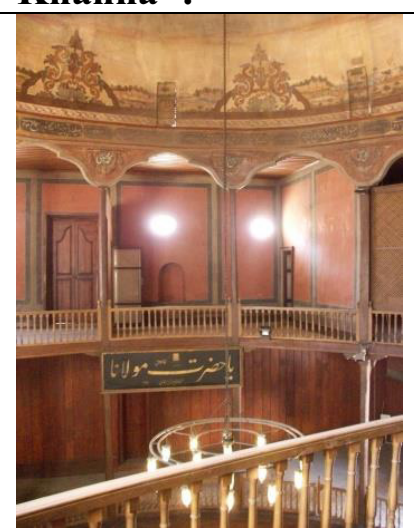

Architectural analysis of the Dervish Theatre:

-The Dervish Theater "Sama Khanna": Mawlawi Zikr Hall is one of the architectural spaces of the Mevlevi Tekkeyya.

-It was erected independently in an architectural block

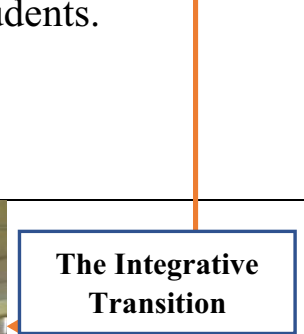

Figure 18 illustrates the Architecture and Interior design of Dervish Al mawlaweyya theatre in which the Sufisk zikr was practiced inside.

The picture illustrates the ottoman features and motifs in the interior desgn such as the Arches, Colours of wall treatments and paintings of the dome.

- The excavations resulted in showing the original layout of the Mameluks Madrasa "school", and it consisted of A Central Open Hall, Two Iwans and Khalwaat (small rooms) for students.

Figure 19 illustrates the view of the Dervish theatre built on the ruins of Sunqur Al saadi Madrasa "school", and after restoration of it between the Italian Institute of Culture and the Egyptian Antiquities Organization. (Photographed

by Researcher) separate from the rest of the Tekeyya, but it is connected to the Sunqur Al Saadi Madrasa "School" from one of its sides, as it was built on the ruins of the demolished parts of the Madrasa.

-The Dervish Theatre hall internal area is $\mathbf{1 5 m}$ x $15 \mathrm{~m}$, covered by a wooden dome with a diameter of $\underline{\mathbf{1 0 . 6 5} \mathbf{m}}$, resting on a circular wooden arch, which in turn is based on twelve wooden columns. The Dome is designed acoustically for Sufism Theatre purposes including "Zikr and Mawlaweyya Dacing". The hall has a wooden upper balcony in the second floor overlooks the main space of the hall on the lower (ground) level.

The analysis in the Table $^{6}$ illustrates the relation between the Mameluks part and the ottoman part as an Integrative transition through Architecture and Interior Design. 
5.4 The philosophy of the Dervish Theatre related to Zikr and Sufism-Mawlaweyya Dancing (The Whirling Dervishes):

The "Dervish Theatre" was called "Sama Khana in Turkish" which referred to the word Samaa in Arabic Language which means "To Hear" during Al Zikr and Mawlawya Dancing and as a kind of Religious determinant in Islam.

This Religious Determinant reflected on the Interior design of the Dervish theatre which was achieved through Plan Design of the Theatre.

The performance of the Mawlawi Sufi dance in the "Samaa" listening Zikr is in the form of two circles of rotation. They line up regularly, so the circle is the basic form in the interior design of the hall.
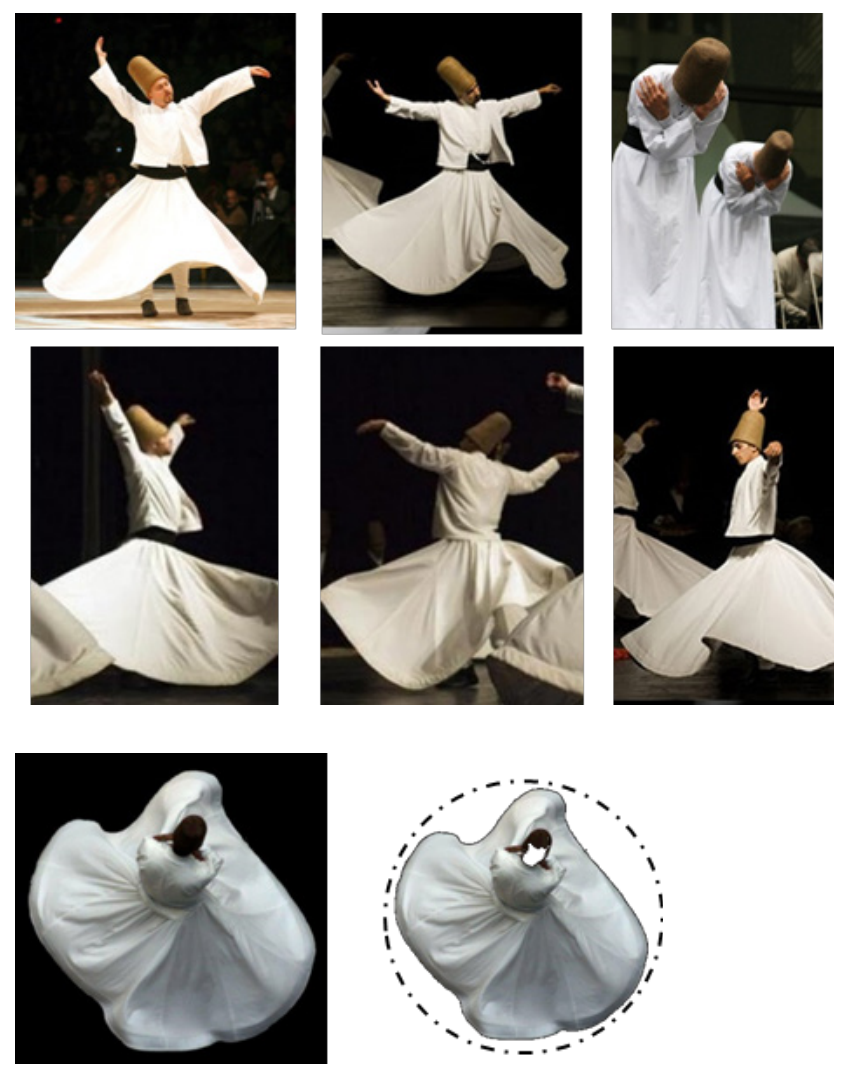

Figure 20 illustrates the whirling Dervishes and the steps of Dancing from right to left, also the different forms of the dervishes with their clothes during Rotation and Mawlawyya dancing.

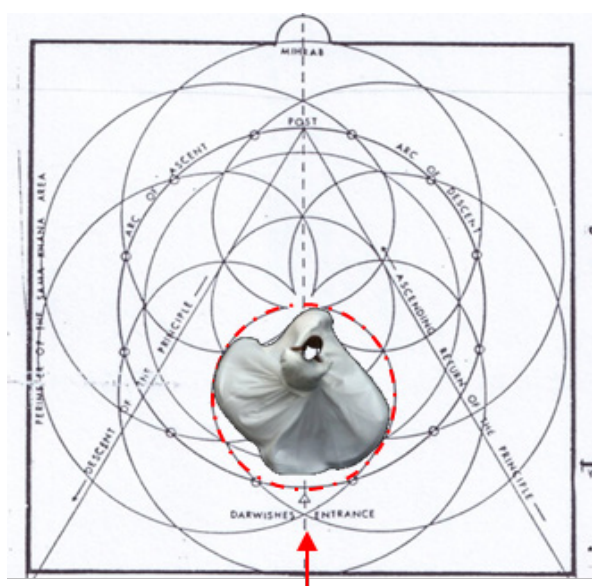

Figure 21 The position of the Mevlevi is shown in the plan view of the Whirling Dervish Sikhs. The Mawlawi was drawn and illustrated within the circle specified for him on the horizontal plan

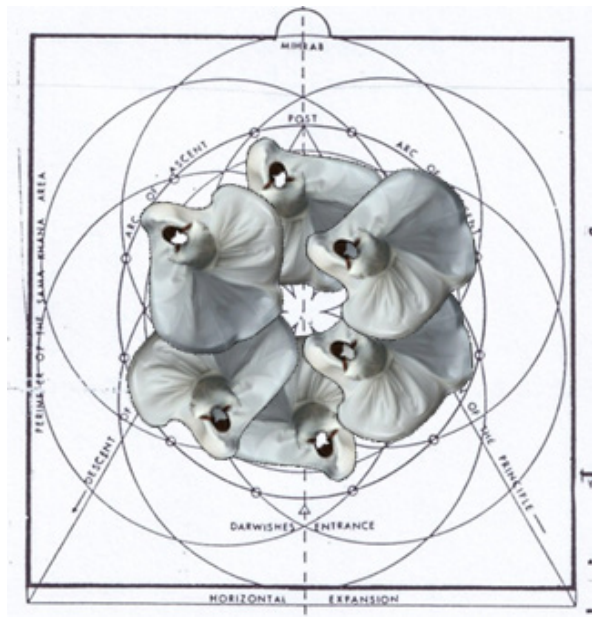

Figure 22The map of the circles depicted on it shows the circular rhythmic movement that resulted from the rotation of the whirling dervishes as a result of the intersection of their robes, and which was used in the design of the horizontal projection of the Dervish Theater - the Dervish Sema. And to the top is the mihrab, which is located inside the Dervish Samkhana - the Mevlevi Museum

In order to reach the reality of the architecture and Interior design of the hall, a radius equal to any of the two circles of the dervish rotation during the performance of the Zikr was taken, then other circles are drawn from the point of intersection of the circles with the horizontal axis from one center, so this indicates the six movements that signify the creation of the universe in six Days.

By connecting the intersection points of the six circles between them in a circle, the second circle resulting from the rotation of the dervishes during the dance is reached. We find this clear in the poems of Jalal al-Din al-Rumi, and he expressed it by saying: 


\section{The six sides are a ship with six angles ... and it is a vast sea without a shore}

The previous Poetry Explains the dynamic rhythm of circulation related to Al Zikr whose philosophy lies in melting into the universe, "and everyone in an orbit they swim," so it begins with raising the right hand to grant from God the Great Creator, and the left hand is directed towards the people of the earth to give, and the rotation is repeated to infinity.

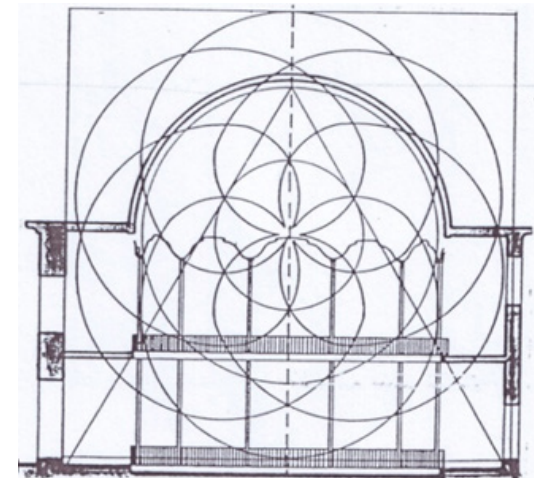

Figure 23 illustrates the circular rhythmic movement between the circles, which resulted from the rotation of the whirling dervishes as a result of the intersection of their robes, which was used in the design of the Section.

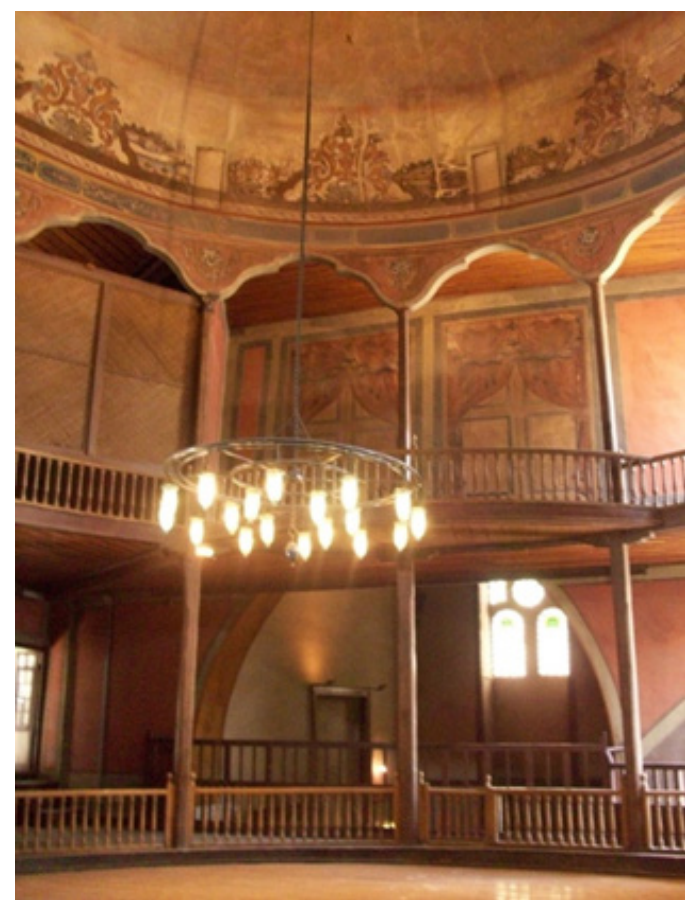

Figure 24 illustrates the Interior design of The Dervish Theatre Hall which was designed according to the Intersection of circles of the Dervishes during Al Mawlaweya dancing.

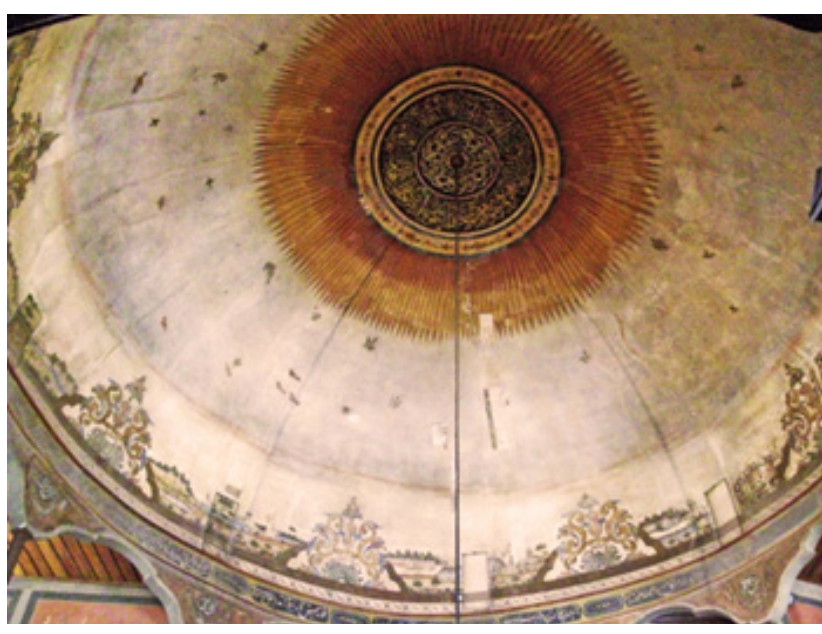

Figure 25 illustrates the Interior design of the Dome of The Dervish Theatre. The dome painted from inside with paintings inspired from the ottoman era, also it was designed with 12 openings in the form of small doors.

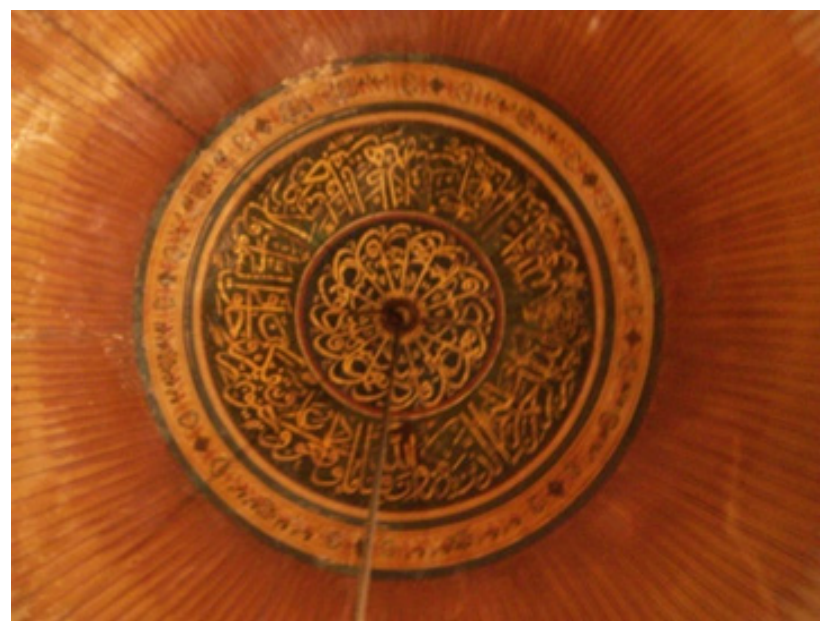

Figure 26 shows the shape of the writings inside the dome of the theater, which is symbolized by the sun.

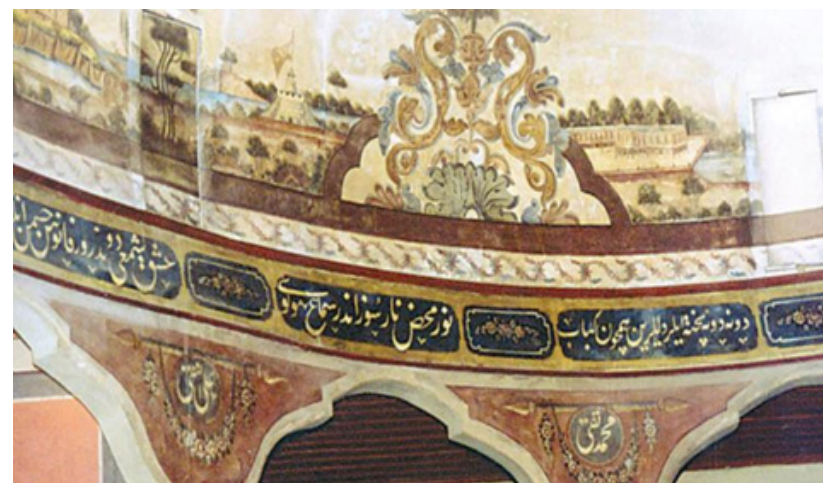

Figure 26 shows the shape of the writings inside the dome of the theater, which is symbolized by the sun. 


\section{Research Conclusion}

The Research concluded the Integrative Transition between The Mameluks and The Ottoman Eras through the Architecture and Interior Design of Sunqur Al Saadi School "Madrasa" and the Dervish Theatre. This Integration achieved by studying the way the dervish theatre was built on the ruins of Sunqur Al Saadi School and The Mausoleum, also the way they were connected for achieving the integration through the transition of different Islamic Eras. The Sunqur Al Saadi School and The Dervish Theatre were built as a result of a Religious determinant: The first as a place for studying the Islam Religion in the small rooms, and as a Mausoleum. The Theatre was built for $\mathrm{Al} \mathrm{Zikr}$ and Mawlaweyya Dancing related to Sufism and the Interior design resulted from the Mawlaweyya cloth and their intersection in the Hall, thus achieving the Integrative transition through the Islamic Religion which impacted on the Architecture and Interior design.

\section{-Research Results}

1. The Role of Islamic Values and Religious determinants in the Integration between the Mameluks and The Ottoman Eras and its reflection on the Architecture and Interior design of Sunqur Al Saadi Complex and The Dervish Theatre.

2. The Unity of Islamic Architectural and Interior Design elements which signified through the different Islamic styles on which the Building was built.

3. The Advantages from the method of Integration between: The architectural and interior design of "Sunqur Al Saadi "Madrasa" School and The Dervish Theatre" and its way of applying in modern Theatres with functional considerations of Acoustics.

\section{-References}

-Abdel Kareem, Ahmed. (2012, p.21) Rhythmic systems in the aesthetics of Islamic art. Egypt: Egyptian General Book Authority.

Abou Golel, Hamdi. (2013, p.106) Cairo Mosques and Tales.

Egypt: Egyptian General Book Authority.

-El Alfy, Abou Saleh. (1967, p. 225) Islamic Art (Origins,
Philosophy, Schools). Egypt: Dar Al Maaref, Second Edition.

- Alsayed, Suad Ramadan Ibrahim: Architectural

Restoration of

Historic Buildings in Egypt Towards an Integrated Framework

(An Applied Study on the Hall of the Mawlawi in al-Suyufiyah),

PhD Thesis, Department of Architectural Engineering, Cairo

University (2005), P. 50

-Rizk, Asim Muhammad. (2003, p. 465) Atlas of Islamic and Coptic Architecture in Cairo. Egypt, Cairo: Madbouly Library, Book 1.

-Khapra, Ravish. Things to see and Do in Konya: Land of the Whirling Dervishes, Available at: https://travelwideworld.com/things-to-see-anddo-in-konya (Accessed: 23 March 2021)

- https://www.alkhaleej.ae/

(Accessed: 12 March 2021)

-Mevlevi Samakhana Conservation. Available at: https://archnet.org/sites/728 (Accessed: 22 March 2021)

-https://www.britannica.com/topic/Mawlawiyah (Accessed 11 August 2021)

-All Photos Photographed by the researcher in the Mawlawya Museum - Egypt) / the Italian Institute of Culture and the Egyptian Antiquities Organization - Al-Suyufiyah Street, Cairo, Egypt. 